\title{
Synergies of the Liberalization of the Railway Transport Market
}

\author{
Michal Panák ${ }^{1}$, Eva Nedeliaková ${ }^{1}$, Borna Abramović ${ }^{2, *}$, and Denis Šipuš ${ }^{2}$ \\ ${ }^{1}$ University of Žilina, Faculty of Operation and Economics of Transport and Communications, \\ Department of Railway Transport, Univerzitná 8215/1, 01026 Žilina, Slovakia \\ ${ }^{2}$ University of Zagreb, Faculty of Transport and Traffic Sciences, Department of Railway Transport, \\ 10000 Zagreb, Croatia
}

\begin{abstract}
The liberalization of transport market brings various effects, which in the context of the assessment of synergies can affect in different ways the company, a customer as such, and transport undertakings operating on the railway transport market as well. This paper provides an innovative perspective on the relationship between liberalization and synergy, defining new types of synergies that have not yet been monitored in the conditions of railway transport. This approach is interesting because of the possibility of assessing the operation of railway undertakings in the open transport market. The eminent is characteristic of integration type synergies and emergence type synergies in relation to railway transport, as well as the breakdown of synergies in relation to the customer and carrier.
\end{abstract}

\section{Introduction}

In the nineties of the last century, the opening of borders and the associated emergence of new opportunities had an impact on transport. After such changing conditions it was the road transport that adapted in the best way possible. A great quantity of freight transport was moved to the road, and the public passenger transport underwent a similar change, with passengers starting to use individual road transport. Because of this development, the traffic load on roads increased significantly. The opening of the transport market and the lengthy preparation of conditions on the liberalization of railway transport market caused further decline in the share of railway transport on the transport market.

One of the possibilities of the global transport market and promotion of the improvement of railway transport services is liberalization, i.e. opening of the transport market, entry of carriers on the market on non-discriminatory terms.

Specification of measures to achieve interoperability and security on the entire continent is evident from the draft legislation in 2002, and the progress of work on the implementation of the adopted EU legislation. In addition to liberalization, the emphasis is

\footnotetext{
*Corresponding author: babramovic@,fpz.hr
} 
on safety and technical uniformity. This means that Member States must restrict adoption of new national safety regulations in order to harmonize them. Another objective is the interoperability aimed at an optimal level of technical harmonization.

The first task was to ensure the EU legislative and institutional coordination in the development of European standards within CEN, CENELEC, ETSI and UIC AEIF and their implementation into national systems of EU countries. A parallel task is to coordinate the preparation of technical specifications for interoperability of high-speed and conventional railways along with the implementation into the national environment. At present, the role of ensuring interoperability at European level is provided by the European Railway Agency.

The basic objective of adopted EU legislation is therefore enlarging market share using market forces to ensure the competitiveness of the rail sector. Railway transport services are the most difficult area to liberalize compared to other modes of transport, because infrastructural and technical standards are very complex, specific and vary largely between Member States. Apart from a few high-speed passenger trains, cross-border trains generally have to change locomotives and crews at the borders, which results in delays and higher costs. This is one of the main reasons for the low competitiveness of rail transport. It is of utmost importance to address the issue of monitoring synergies of liberalization of the transport market, since these effects may not always have a positive character. At the same time, however, it should be added that entry of new carriers on the transport market could lead to an increase in the supply and quality of railway transport services.

\section{History and legislative regulation}

The initial tendency to commence reforms of transport market in Europe was Directive 91/440/EC, which demanded accounting departments in historical railway undertakings. The directive has allowed access to national infrastructure within an international transport, which manager of infrastructure was obligated to charge [1]. This directive was followed by another one, Directive 95/18/EC concerning licensing transport undertakers, and then subsequent Directive 95/19/EC concerning railway infrastructure allocation and infrastructure charges.

Because the reform of European railway market was progressing slowly, four other directives were released to speed it up:

- 12/2001/EC - increased independence of railway undertakers, especially infrastructure managers from national budgets of state members. The Directive demanded strict separation of freight transport accounting from personal transport accounting, and within the personal transport avoiding cross-financing. This Directive is well-known for the definition of "Trans European Rail Freight Network". [2] Free access to services was to be included in this network as from 2003. A complete liberalisation of international railway freight transport was planned for 2008 .

- 13/2001/EC - established common access to licensing railway undertakers and required mutual acceptance of licences within state members.

- 14/2001/EC - according to this Directive, an infrastructure manager had to introduce surcharge to marginal costs of charging infrastructure, by means of free and nondiscrimination politics.

These three aforementioned directives were part of the so-called "First Railway Package", also referred to as Infrastructure package. Member States were obliged to incorporate the directives of this package into their national legislations until 2003.

First package was followed by "Second Railway Package" adopted in 2004 incorporated into national legislation by April 2006 [1,3]. A part of its measures was the 
directive about railway safety, and a significant fact was the establishment of "European Railways Agency". Second Railway package changed Directive 96/48/EC about international operation of high-speed railway system and its part has become Directive $16 / 2001 / \mathrm{EC}$, which discussed about interoperability in conventional transport.

"Third Railway package" tackles issues about compensations in case of non-compliance with contractual requirements on service quality, about passengers' rights and obligations and in a sense of liberalisation, the main part is about personal railway transport.

Part of "Fourth Railway package" includes the following directives, with a transposition deadline on or before until 16 of June 2019 [1, 4]:

- Directive EP and the Council of the EU 2016/797 of 11 May 2016 on interoperability of railway systems in EU.

- Directive EP and the Council of the EU 2016/798 of 11 May 2016 on railway safety.

Another major change in legislation is the Proposal for regulation of the Committee relating to fees paid by railway undertakings for EUAR. [1] This proposal adjusts charges and payments for services of EUAR resulting from the Regulation 2016/796 of the EP and the EU Council of, calculation methods, payment terms, and conditions.

Liberalisation of international railway transport is a key question when it comes to support of railway transport as an ecological way of transportation, which is why it is so important to monitor the impact of it on society, individuals and transport undertakings [1, $4,5]$. In the research, we monitored and defined different types of synergies that can emerge on the transport market regarding the new conditions in case of a new transporter entering the market.

\section{Synergy and its relation to liberalization}

The main reason for synergies in railway transport is their growing importance, and if required - operative interventions to railway operations that affect the quality of services. In these cases, there are many dynamic factors that affect the quality negatively, which evolve constantly over time. In most cases, it goes about unsatisfactory communication between infrastructure managers and carriers, which has a significant impact on the quality of services provided. This situation then ultimately affects satisfaction and the needs of existing customers of railway undertakings, as well as decisions of potential customers about the use of railway transport for the future.

Due to a very wide range of tasks and cooperative collaborations of two or more subsystems (external business partners, internal organizational units, teams, etc.), synergy in its management applications is very widespread with diverse content. Therefore, it is necessary to establish appropriate classification effects arising from their acts [6]. For the classification of the type of synergy that can be a source of inspiration for modern management, synergies are defined as a cooperation between manager infrastructure and carriers according to these prominent authors:

\section{A) Peter A. Corning [7]}

- Synergy of functional complementarities - are the cases synergy that accrues from accouplement accessories. Nowadays, the emphasis is placed on the effective cooperation within the meaning of the communication between manager of the railway infrastructure and the carriers whose services for customers each represent complements, i.e. they are linked, unable to exist without each other.

- Synergy of emergent phenomena - present in the cases of qualitative changes that occur due to mutual internal interaction of partial subsystems. In the implementation of the quality management system of railway undertakings, it is about an effort to improve 
services. Qualitative changes are necessary for the effective functioning of railway undertakings on the transport market. Their implementation is difficult in terms of time and people factor, but they bring significant effects in logistics processes. Moreover, it is usually difficult to convince railway infrastructure managers and employees that change is necessary.

- Synergy of a combination of labour - the case of this synergy refers to the creation of conditions for the collection of the same or similar activities, so that individual activities are not conducted twice and so that the division of labour would stay fair.

B) Igor H. Ansoff [8]

- Sales synergy - arises when different services use shared distribution channels or selling points. In the case of railway passenger transport, it is the sale of different types of travel documents on the whole railway network and transport alone.

- Operating synergy - it results from the economical use of facilities and personnel of railway undertakings.

- Investment synergy - this synergy category is the result of improved recovery of resources. In railway undertakings, it refers to a more effective management of logistics processes (management of wagons, management of drive railway vehicles, management of invest resources to maintenance and repairs of railway infrastructure, and etc.).

- Managerial synergy - it occurs when the new railway undertakings recover existing wellestablished management knowledge.

C) Robert S. Kaplan and David P. Norton [9]

- Financial synergy - it is the integrated management of logistics processes in the value chain of business activities of the railway undertakings.

- Customer synergy - creation and implementation of joint offers to customers. In relation with transport services, it comes to getting and keeping satisfied customers.

- Synergy of internal processes - includes practical and effective changes in logistics processes railway undertakings for providing better quality services.

- Learning and growth synergy - association of innovative technologies in the field of logistics processes and customer services.

D) Michael Goold and Andrew Campbell [10]

- Integration type synergies

- Emergence type synergies

Integration type synergies belong to the synergy whose effects can be quantitatively evaluated. They arise out of the cooperation between minimally two partial processes of different levels of management railway undertakings. They are processes that can be objectively monitored using, for example, statistical methods of quality management. Projecting and using the integration type synergies and their effects are expected in the needed time period as it is characterized in the following Figure 1. 


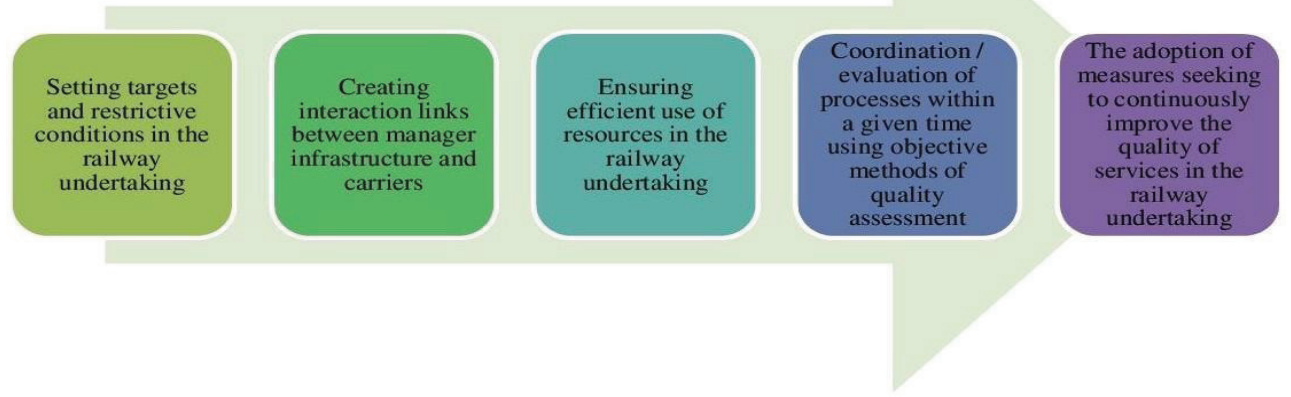

Fig. 1. Projection and use of integration type synergies and their effects in a time sequence. Source: authors

The basic idea for the formation of models synergies of integration type is a suitable distribution (allocation) or redistribution (reallocation) of activities and considered resources subsystems, and their use in favour of functioning of systems that create these subsystems. Contrario sensu are the emergence type synergies, in which arising effects are completely or largely qualitatively different from resources subsystems. [9] In one of their publications, Goold and Campbell report that "the results of emergence effects are manifested in the features, in the abilities to behave and in the results system of managerial work as a whole".

There are various types of models closely related to this synergy. One of them is Model of Critical Success Factors [5, 10, 11]. For modification processes with focus on the railway transport, see the following Figure 2.

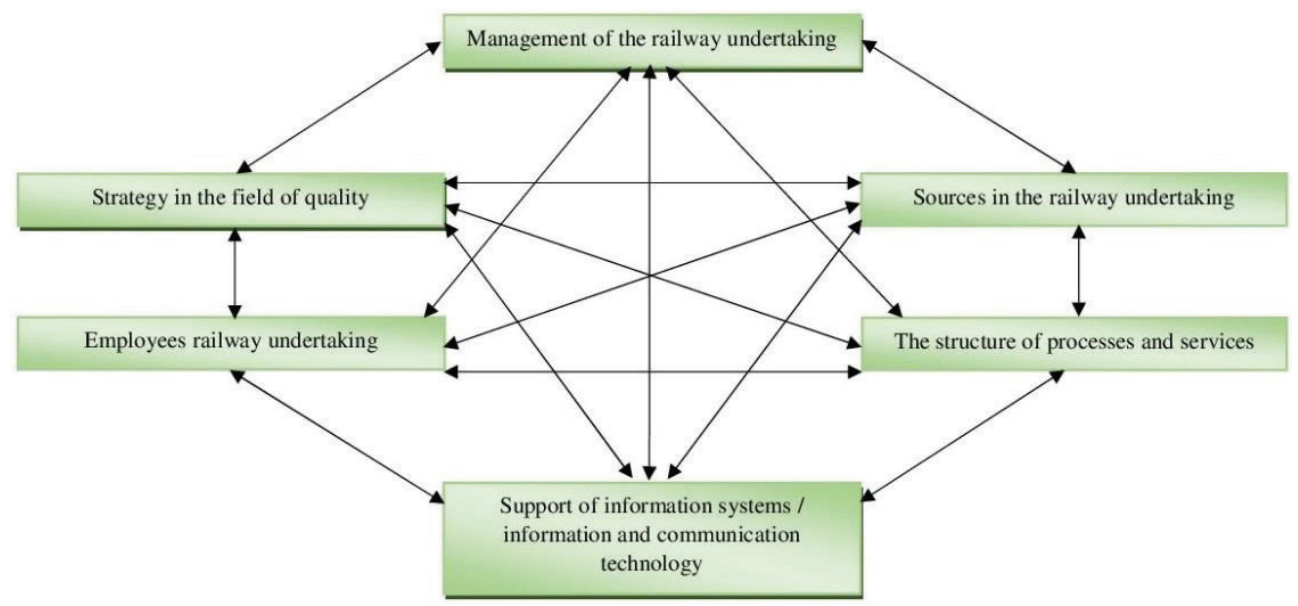

Fig. 2. Model Critical Success Factors railway undertaking and their book bands on the internal synergies. Source: authors

The purpose of the Model of Critical Success Factors is to focus attention of railway infrastructure managers on those aspects of their work that are essential for a more efficient provision of services. As far as the outputs are concerned, there are suitable selected arrangements of indicator activities for this undertaking. These indicators are characterized by prosperity, stability, competitive position, and others. The functioning of individual subprocesses is modified depending on their interactions with each other [5]. This 
interaction can vary in time, and emerging synergies may change over time, such as changing the quality of services.

These synergies significantly affect the performance of transport undertakings on the liberalized transport market, but also the customer service.

\section{Basic types of synergies on the transport market}

As already mentioned, synergy can be understood as a cooperation between infrastructure manager and carriers, or carriers to carrier, and customer to carriers, in terms of one mode of transport or a combination of several. At the same time, synergies can also work from outside business environment. These can be both positive and negative. As can be seen in Figures 3 and 4, synergies of liberalization can be distinguished from those that act on the customer and those that act on the carrier.

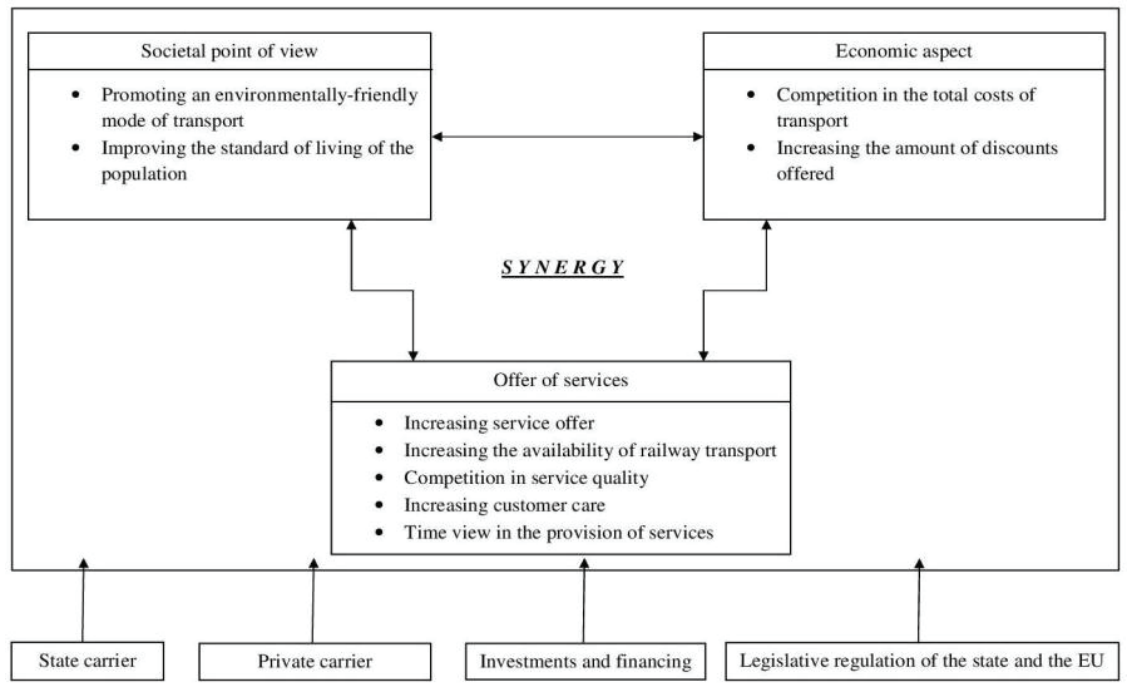

Fig. 3. Synergies of liberalization in connection with customer. Source: authors

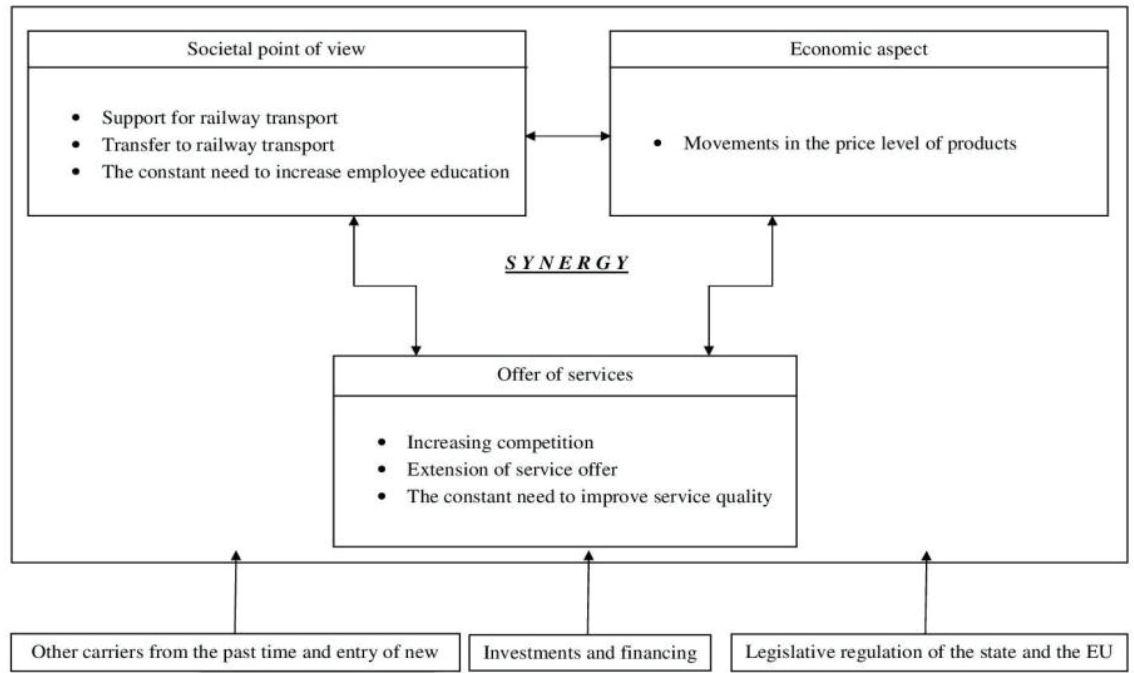

Fig. 4. Synergies of liberalization in connection with carrier. Source: authors 
These synergies are closely linked to the competitiveness of railway transport more than other modes of transport. To create competitiveness in the railways, the EU has taken the path of separating rail infrastructure from rail services, although the success of such initiatives has varied under the terms of specific Member States. The current ability of service providers to take advantage of such rules depends on the willingness of States to help them [12]. Training of crew and certification for equipment can be a major obstacle for market access. For example, it took France and Germany years to mutually certify their respective high-speed trains for operation on the Paris-Frankfurt railway, which became operational in 2007. Also, the result of the White Paper on transport are several policy initiatives including encouraging the liberalization and harmonization of Europe's railway systems.

The European Union supports increasing the competitiveness of rail passenger services in the interests of the environment, and enhancing the quality of provided services. The revitalisation of rail transport on the European transport market is a challenging tasks, particularly because of inconsistencies in terms of national networks, the technical incompatibilities of rail systems, but also due to legislative restrictions [6]. The governments of some countries block the opening of passenger transport networks so as not to allow foreign companies access to their markets. A bright spot that determines the steps to liberalization of international passenger transport was the third railway package, which defined the year 2010 as the main objective of liberalization.

\section{Conclusion}

The opening up of railway sector to competition is given by the EU's approach in this area, which has gradually adopted legislation determining the direction and pace of liberalization railway sector binding for Member States.

Railway transport in the past constituted the basis of the transport system of individual European states, but it began to lose importance with the development of air and road transport. The fact that railways failed to respond to competitive pressure, in particular on road transport, resulted from two main reasons. The first is that railways were organized on a national principle - networks were built as national, taking into account national and regional requirements and therefore there was no interoperability. The second problem was that railways were large undertakings historically owned, controlled and regulated by the state, so they were not efficient and flexible enough to respond to changes in customer demand for transport. For these reasons, railways were unable to capture the potential of international cooperation and foreign trade growth, losing their overall position in the field of transport, particularly in favour of road transport.

The research into two major international projects has highlighted the clear importance of monitoring synergies in relation to liberalization. New synergies have been defined in relation to the customer and carrier, even when a new carrier enters the transport market. Research underlines that assessment of synergies significantly affects supply of services, quality of services, and the constant need to increase employee training. Synergies in relation to liberalization are one of the decisive factors that can affect the transfer of railway transport and promote the ecological aspect of transport. This research is also innovative in that it addresses the idea of raising the standard of living of the population. 
This research was financially supported by the project KEGA 010ŽU-4/2017 "New methods of teaching quality management in the study program Railway transport with a focus on optimization of extraordinary events in terms of customer orientation" - Faculty of Operation and Economics of Transport and Communications, University of Zilina and the PROM - PRO - project "Adapting the railway system in the integrated passenger transport (ARSIPT) " solved at Faculty of Transport and Traffic Sciences, University of Zagreb.

This paper is supported by the research project "From horse-drawn railway to intermodal transport" within Visegrad Fund.

\section{References}

1. A. Tomová, Models of structural reform of railways (University of Žilina/EDIS university press, Žilina, Slovak Republic, 2010)

2. B. Boskovic, M. Bugarinovic, Transport Policy 41, 50-59 (2015), DOI: 10.1016/j.tranpol.2015.03.009

3. J. Kintler, Managing and modelling of financial risks - 7th international scientific conference, 358-366 (VŠB - Technical University of Ostrava, Czech Republic, 2014)

4. M. Jandova, T. Paleta, European Regulation of the Railway Transport - the $1^{\text {st }}$ Railway Package Recast and the $4^{\text {th }}$ Railway Package Proposal (2013), DOI: 10.5817/CZ.MUNI.P210-6425-5

5. E. Nedeliakova, M. Panak, BEM2015 - International Scientific Conference: Business Economics and Management, 172-179 (Procedia Economics and Finance 34, 2015), DOI: 10.1016/S2212-5671(15)01616-0

6. E. Nedeliakova, B. Abramović, M. Panak, Support for new approach within rail freight transport leading to creation of favourable conditions in transport market (University of Žilina, Slovak Republic, 2015)

7. P.A. Corning, Nature's Magic. Synergy in Evolution and the Fate of Humankind (Cambridge University Press, Cambridge, 2003)

8. I.H. Ansoff, Implanting Strategic Management (Prentice Hall, Englewood Cliffs, 1990)

9. R.S. Kaplan, D.P. Norton, The Execution Premium. Linking Strategy to Operations for Competitive Advantage (Harvard Business Press, Boston, 2008)

10. M. Goold, A. Campbell, Desperately Seeking Synergy (Harvard Business Review, Cambridge, 1998)

11. E. Nedeliakova, M. Panak, J. Ponicky, R. Sousek, Proceedings of the 2016 International Conference on Engineering Science and Managament, 195-198 (ERAdvances in Engineering Research 62, 2016)

12. V. Stefancova, E. Nedeliakova, C. Lopez-Escolano, 12th international scientific conference of young scientists on sustainable, modern and safe transport, 834-839 (Procedia Engineering 192, 2017), DOI: 10.1016/j.proeng.2017.06.144 